\title{
振幅変調および強度変調レーザ光の出力 $\mathrm{SN}$ 比
}

\author{
大下 真二郎*・森 永 規 彦**・滑 川 敏 彦**
}

Output Signal-to-Noise Ratios for Amplitude and Intensity Modulated Lasers

Shinjiro Oshita*, Norihiko MorinagA** and Toshihiko NAMEKAWA**

The general expressions of the autocorrelation function and the output SNR of a photodetector are derived for a coherent laser either amplitude of intensity modulated by a stationary Gaussian random modulating signal in the presence of background light. Two types of the modulationg signal are considered: the baseband and the bandpass modulating signals. The effects of the center frequency of the modulating signal, the modulation degree, the effective average quantum rate, the wave interaction noise, the shot noise, the modulation method, and the input CNR on the output SNRs are discussed. It is shown that the output SNRs increase as the modulation degree, the effective average quantum rate, and the input CNRs become large. The bandpass modulating signal is better than the baseband modulating signal when the effective average quantum rate and input CNRs are large.

It is also shown that the intensity modulation is superior to the amplitude modulation only for the baseband modulating signal case with large effective average quantum rate and large input CNR. This paper gives results useful for the field of laser communication.

\section{1. まえがき}

レーザ応用は非常に広い分野にわたるものである が. その内，レーザ計測，レーザ通信などの分野にお いては，時間的に変動する何らかの信号（情報）によ って変調された，いわゆる被変調レーザ光を取扱う場 合が多い，乙の場合，最む多いのが $\mathrm{AM}$ 系(注 1)であ るが, $\mathrm{AM}$ 系は普通, 振幅変調と強度変調とに分類 される.また信号処理の観点からすれば，アナログ $\mathrm{AM}$ 系とディジタル AM 系とにわけるととができ

* 信州大学工学部 長野市若里 500

** 大阪大学工学部 吹田市字山田上

* Faculty of Engineering, Shinshu University, Nagano

** Faculty of Engineering, Osaka University, Suita (Received November 8, 1972)
る. このように分類して考えた場合, ディジタル $\mathrm{AM}$ 系関しては通信分野子関連して，その方式，特性に ついてかなり詳しく解析され, 報告された文献も相当 数にのぼっている(1) 5).

とてろで一方アナログ $\mathrm{AM}$ 系汇関しては通信打よ び計測分野においてよくみうけられ，たとえば変調周 波数を用いた測距方式や ${ }^{6)}$ ， マイケルソン形干渉計を 用いた精密測長方式 ${ }^{7)}$ ，に求いてもレーザ光の強さは 変調を受けているし，あるいはまた，同期方式を採用 した微弱光検出方式に和けるアナログ処理や8), 実時 間光相関器9,10)などあアナログ $\mathrm{AM}$ 系とみなせる.

てのように計測分野に执いてはアナログ AM 系が非 常に多いわけであるが，その反面，アナログ $\mathrm{AM}$ 系 に対する光検波特性に関しては, 復調信号出力に対し てショット雑音のみを考慮した近似的な特性しか求め られていないし ${ }^{11)}$, 被変調レーザ光と背景雑音光との 光検波器における相互変調作用や波動干涉雑音の影 響, あるいは振幅変調之強度変調との光検波出力に招 ける違いなどすべて不明膫なままで, 出力 $\mathrm{SN}$ 比を より厳密に論じるには不十分な状況にある.

本論文では以上のてとを念頭において，アナログ $\mathrm{AM}$ 系に対し, 被変調レーザ光と背景雑音光とが光検 波器の入力となる場合の出力 $\mathrm{SN}$ 比について, 一般 的並びに数值解析を行なってより厳密に出力 SN 比 の特性を論じている.すなおち, 変調信号として，0 周波数近傍にスペクトル分布を有するベースバンド変 調信号および高い中心周波数のまわりにスペクトル分 布を有するバンドパス変調信号の二種類を仮定し，変 調度, 実効光電子数, 入力 $\mathrm{CN}$ 比, の各パラメータ や, 波動干渉雑音, ショット雑音, あるいは变調信号 の種類の違いや，振幅変調々強度変調の違い，などが 出力 SN 比汇いか影響を及ぼすかを詳しく解析し， アナログ AM 系を対象としたレーザ計測の出力特性 に関する評価の際の有用な資料を与えている。な怙本

（注 1） 本論文では振幅変調と強度変調をまとめて AM 系と 呼ぶととにする. 
論文では，変調信号として一般的にランダム信号を仮 定しているが，たとえ周期的な正弦信号を扱かう場合 でも，本論文で得られた結果と本質的な差異はない。

\section{2. 振幅変調レーザ光に対する出力 $\mathrm{S} \mathrm{N}$ 比}

\section{1 一般的解析}

Fig. 1 に示されているアナログ AM レーザ系の 光検波器の入射電界 $V(t)$ は振幅変調レーザ光と背景 雑音光之からなっており，次式で表わされる ${ }^{12)}$.

$$
V_{A}(t)=\left(1+V_{s}(t)\right) V_{x}(t)+V_{n}(t)
$$

ことに，実関数 $V_{s}(t)$ は変調信号であって平均値 0 の定常からプロセス，また複素電界 $V_{x}(t), V_{n}(t)$ は レーザ光および背景雑音光を示して拉り，乙れらすべ ては統計的に独立であるとする。

また本論文では過変調はないものとして $1+V_{s}(t)$ $\geq 0$ と仮定するが，ガウス形ランダム変調信号の場合 にはその平均電力 $P_{s}$ が $9^{-1}$ より小さければ $1+V_{s}$ $(t)<0$ となる確率はわずかに $0.136 \%$ 以下に過ぎず 過変調はないあのとみて差支えないので，以下 $P_{s} \leq$ $9^{-1}$ として解析を進めることにする。

このような入射電界 $V_{A}(t)$ に対する瞬時強度 $I_{A}(t)$ および平均強度 $\left\langle I_{A}(t)\right\rangle$ はつぎのように与えられる

$$
\begin{aligned}
I_{A}(t)= & V_{A} *(t) V_{A}(t)=\left(1+V_{s}(t)\right)^{2} V_{x} *(t) V_{x}(t) \\
& +V_{n} *(t) V_{n}(t)+\left(1+V_{s}(t)\right)\left(V_{x} *(t) V_{n}(t)\right. \\
& +V_{x}(t) V_{n}^{*}(t) \\
\left\langle I_{A}(t)\right\rangle & =\left\langle V_{A} *(t) V_{A}(t)\right\rangle=\left(1+P_{s}\right)\left\langle I_{x}(t)\right\rangle+\left\langle I_{n}(t)\right\rangle
\end{aligned}
$$

ただし，＊〈〉は複素共役扔よび平均操作を意味 し，〈I $(t)\rangle,\left\langle I_{n}(t)\right\rangle$ はそれぞれレーザ光と背景雑音 光に対する平均強度を示しており次式で与えられる。

$$
\begin{aligned}
& \left\langle I_{x}(t)\right\rangle=\left\langle V_{x} *(t) V_{x}(t)\right\rangle \\
& \left\langle I_{n}(t)\right\rangle=\left\langle V_{n} *(t) V_{n}(t)\right\rangle
\end{aligned}
$$

つぎに，乙の入射光電界に対する光梌波器の応答に こいて考え，出力電流に対する自己相関関数を導く. 光検波器の出力電流は入射光強度に比例した確率で放 出される光電子によって生じると考えられる.

いま時刻 $t$ から $t+\delta t$ の間に一つの光電子が放出 される確率は, 入射光の平均強度 $\left\langle I_{A}(t)\right\rangle$ に関して

$$
P_{1}(t) \delta t=\frac{1}{2} \alpha\left\langle I_{A}(t)\right\rangle \delta t
$$

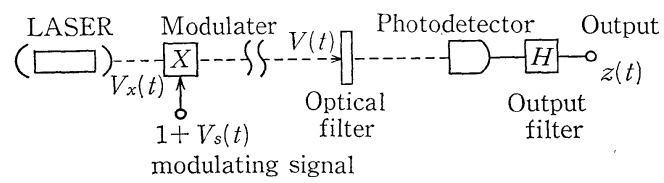

Fig. 1 Optical detection system for amplitude and intensity modulated laser
で与えられる ${ }^{12)}$.ただし，係数 $1 / 2$ は電力と強度との 比を示すあのであり，また光検波器の感度 $\alpha$ は次式で 与えられる

$$
\begin{aligned}
& \alpha=\frac{\eta}{h F_{0}} \quad \eta: \text { 量子効率 } \quad h: \text { プランク定数 } \\
& F_{0}: \text { レーザ周波数 }
\end{aligned}
$$

一般には，時刻 $t_{1}, t_{2}, \cdots t_{L}$ ，と $t_{1}+\delta t_{1}, t_{2}+\delta t_{2}, \cdots t_{L}+$ $\delta t_{L}$ のそれぞれの間に放出される $L$ 個の光電子に関す る結合確率は

$$
\begin{aligned}
& P_{L}\left(t_{1}, t_{2}, \cdots t_{L}\right) \delta t_{1}, \delta t_{2} \cdots \delta t_{L} \\
& \quad=2^{-L} \alpha^{L}\left\langle I_{A}\left(t_{1}\right) I_{A}\left(t_{2}\right) \cdots I_{A}\left(t_{L}\right)\right\rangle \delta t_{1}, \delta t_{2} \cdots \delta t_{L}
\end{aligned}
$$

で示される、いまこれらの光電子による電流パルスを 近似的にデルタ関数で表示すれば, 光検波器からの出 力電流 $y(t)$ は

$$
y(t)=e \sum_{j} \delta\left(t-t_{j}\right)
$$

で表わされる，たたし， $e$ は電子の電荷である。した がってとの出力電流の自己相関関数 $R_{y}(\tau)$ は

$$
\begin{aligned}
R_{y}(\tau)= & \langle y(t) y(t+\tau)\rangle \\
= & e^{2} \sum_{i \neq j}\left\langle\delta\left(t-t_{i}\right) \delta\left(t-t_{j}+\tau\right)\right\rangle \\
& +e^{2} \sum_{i}\left\langle\delta\left(t-t_{i}\right) \delta\left(t-t_{i}+\tau\right)\right\rangle
\end{aligned}
$$

となる.さらに，(10)式の右辽の第 1 項の平均演算に は，時刻 $t_{i}$ と $t_{j}$ とに二つの電流パルスが同時に現 わ机る結合確率，すなわち，(8)式で $L=2$ の場合 を用い，また第 2 項の平均演算には $(6)$ 式を用いれ ば, $R_{y}(\tau)$ は平均強度 $\left\langle I_{A}(\tau)\right\rangle$ および強度相関 $\left\langle I_{A}(t)\right.$ $\left.I_{A}(t+\tau)\right\rangle$ に関して次式で与えられる ${ }^{12)}$.

$$
\begin{aligned}
R_{y}(\tau)= & \frac{1}{4} \alpha^{2} e^{2} \iint_{-\infty}^{\infty} \delta\left(t-t_{i}\right) \delta\left(t-t_{j}\right. \\
& +\tau)\left\langle I_{A}\left(t_{i}\right) I_{A}\left(t_{j}\right)\right\rangle \mathrm{d} t_{i} \mathrm{~d} t_{j} \\
& +\frac{1}{2} \alpha e^{2} \int_{-\infty}^{\infty} \delta\left(t-t_{i}\right) \delta\left(t-t_{i}+\tau\right)\left\langle I_{A}\left(t_{i}\right)\right\rangle \mathrm{d} t_{i} \\
= & \frac{1}{4} \alpha^{2} e^{2}\left\langle I_{A}(t) I_{A}(t+\tau)\right\rangle+\frac{1}{2} \alpha e^{2}\left\langle I_{A}(t)\right\rangle \delta(\tau)
\end{aligned}
$$

(11) 式は瞬時強度 $I_{A}(t)$ の入射光に対する光検波器出 力電流の自己相関関数である. したがって (11)式に (2)，(3)式を代入すれば出力電流の自己相関関数 $R_{y}(\tau)$ はつぎのように求まる.

$$
\begin{aligned}
R_{y}(\tau) & \\
= & \frac{1}{4} \alpha^{2} e^{2}\left[2\left(1+P_{s}\right)\left\langle I_{x}(t)\right\rangle\left\langle I_{n}(t)\right\rangle\right. \\
& +\left(1+2 P_{s}+4 R_{s}(\tau)\right. \\
& \left.+\left\langle V_{s}^{2}(t) V_{s}^{2}(t+\tau)\right\rangle\right)\left\langle I_{x}(t) I_{x}(t+\tau)\right\rangle \\
& +\left(1+R_{s}(\tau)\right)\left(R_{x} *(\tau) R_{n}(\tau)\right.
\end{aligned}
$$


大下・森永・滑川：振幅変調および強度変調レーザ光の出力 SN 比

$$
\begin{aligned}
& \left.\left.+R_{x}(\tau) R_{n} *(\tau)\right)+\left\langle I_{n}(t) I_{n}(t+\tau)\right\rangle\right] \\
& +\frac{1}{2} \alpha e^{2}\left[\left(1+P_{s}\right)\left\langle I_{x}(t)\right\rangle+\left\langle I_{n}(t)\right\rangle\right] \delta(\tau)
\end{aligned}
$$

ここに, $R_{s}(\tau), R_{x}(\tau), R_{n}(\tau)$ についてはつぎのよう に定義されている.

$$
\begin{aligned}
& R_{s}(\tau)=\left\langle V_{s}(t) V_{s}(t+\tau)\right\rangle \\
& R_{x}(\tau)=\left\langle V_{x} *(t) V_{x}(t+\tau)\right\rangle \\
& R_{n}(\tau)=\left\langle V_{n}^{*}(t) V_{n}(t+\tau)\right\rangle
\end{aligned}
$$

さて，まず変調信号 $V_{s}(t)$ は平均值 0 の定常ガウス 信号であるので, その電力相関については次式のよう になる。

$$
\left\langle V_{s}^{2}(t) V_{s}^{2}(t+\tau)\right\rangle=P_{s}^{2}+2 R_{s}^{2}(\tau)
$$

またレーザ光については，その周波数 $F_{0}$ をすれ ば，その複素電界 $V_{x}(t)$ はつぎのように書ける.

$$
V_{x}(t)=\dot{A} e^{j 2 \pi F_{0} t}
$$

ただし，Aは一定振幅を示している.したがって，乙 のようなレーザ光に対する平均強度 $\left\langle I_{x}(t)\right\rangle$, 自己相 関関数 $R_{x}(\tau)$ および強度相関 $\left\langle I_{x}(t) I_{x}(t+\tau)\right\rangle$ は以下 のようになる.

$$
\begin{aligned}
& \left\langle I_{x}(t)\right\rangle=\left\langle V_{x} *(t) V_{x}(t)\right\rangle=A^{2} \\
& R_{x}(\tau)=\left\langle V_{x}^{*}(t) V_{x}(t+\tau)\right\rangle=A^{2} e^{j 2 \pi F_{0} \tau} \\
& \left\langle I_{x}(-t) I_{x}(t+\tau)\right\rangle=A^{4}
\end{aligned}
$$

さらに背景雑音光に対しては，その電力スペクトル密 度が $F_{0}$ の近傍に分布している定常狭帯域ガウスプロ セスを仮定すれば， $V_{n}(t)$ はつぎのように表わせる。 すなわち

$$
V_{n}(t)=n(t) e^{j\left(2 n F_{0} t+\phi(t)\right)}
$$

ここに, 包絡線 $n(t)$ と位相 $\phi(t)$ はともに $F_{0}$ に比 べて非常にゆるやかにランダムな変動をしている. そ してその平均強度 $\left\langle I_{n}(t)\right\rangle$, 自己相関関数 $R_{n}(\tau)$ およ び強度相関 $\left\langle I_{n}(t) I_{n}(t+\tau)\right\rangle$ は

$$
\begin{aligned}
& \left\langle I_{n}(t)\right\rangle=\left\langle V_{n}^{*}(t) V_{n}(t)\right\rangle=2 P_{n} \\
& R_{n}(\tau)=\left\langle V_{n}{ }^{*}(t) V_{n}(t+\tau)\right\rangle=2 r_{n}{ }^{2}(\tau) e^{j 2 n F_{0} \tau} \\
& \left\langle I_{n}(t) I_{n}(t+\tau)\right\rangle=4 P_{n}{ }^{2}+4 r_{n}{ }^{2}(\tau) . \\
& \text { ただし, } P_{n} \text { は背景雑音光の平均電力で } \\
& P_{n}=P_{n}(0) / 2=r_{n}(0)
\end{aligned}
$$

である。

変調信号，レーザ光および背景雑音光に対する(16) 〜 (25) 式の関係を用いて(12)式を書き植せば，出力自 已相関関数 $R_{y}(\tau)$ はつぎのようになる.

$$
\begin{aligned}
R_{y}(\tau)= & \alpha^{2} e^{2}\left[A^{2}\left(1+P_{s}\right) / 2+P_{n}\right]^{2} \\
& +R_{1}(\tau)+R_{2}(\tau)+R_{3}(\tau)
\end{aligned}
$$

ここに, $R_{1}(\tau), R_{2}(\tau), R_{3}(\tau)$ についてはそれぞれ

$$
\begin{aligned}
R_{1}(\tau)= & \alpha^{2} e^{2} A^{4} R_{s}(\tau) \\
R_{2}(\tau)= & \alpha^{2} e^{2}\left[A^{4} R_{s}^{2}(\tau) / 2\right. \\
& \left.+A^{2}\left(1+R_{s}(\tau)\right) r_{n}(\tau)+r_{n}{ }^{2}(\tau)\right]
\end{aligned}
$$

$$
R_{3}(\tau)=\alpha e^{2}\left[A^{2}\left(1+P_{s}\right) / 2+P_{n}\right] \delta(\tau)
$$

で与えられる. ここに(26)式の右辺の第 1 項は直流成 分, $R_{1}(\tau)$ は出力信号成分, $R_{2}(\tau)$ は波動干渉雑音 ${ }^{13)}$ と呼ばれるもので，信号の 2 次ひずみ成分および背景 雑音光のゆらぎに起因する雑音である. そして最後の $R_{3}(\tau)$ がショット雑音を示している.（26)式にフーリ エ積分をほよ゙とすと光検波器出力電流 $y(t)$ の電力ス ペクトル密度 $W_{y}(F)$ がつぎのように求まる。すなわ ち

$$
\begin{aligned}
W_{y}(F)= & \alpha^{2} e^{2}\left[A^{2}\left(1+P_{s}\right) / 2+P_{n}\right]^{2} \delta(F) \\
& +\int_{-\infty}^{\infty}\left\{R_{1}(\tau)+R_{2}(\tau)+R_{3}(\tau)\right\} e^{-j 2 n F \tau} \mathrm{d} \tau
\end{aligned}
$$

(30)式の電力スペクトル密度をもつ出力電流 $y(t)$ は 次段の出力フィルタで通過带域外の成分を除去されて 出力となる. いま出力フィルタのインパルス応答を $h(t)$ とすれば，(9)式を用いてフィルタ.出力 $z(t)$ は つぎのようになる.

$$
z(t)=\int_{-\infty}^{\infty} y\left(t^{\prime}\right) h\left(t-t^{\prime}\right) \mathrm{d} t^{\prime}=e \sum_{j} h\left(t-t_{j}\right)
$$

この出力 $z(t)$ の電力スペクトル密度は $y(t)$ の電力 スペクトル密度 $W_{y}(F)$ および出力フィルタの周波数 応答 $H(F)$ から求まるので, そのうちの信号電力と 雑音電力の比をとることによって, 出力 $\mathrm{SN}$ 比は以 下のように求まる

$$
\left(\frac{\mathrm{S}}{\mathrm{N}}\right)=\frac{\int_{-\infty}^{\infty}|H(F)|^{2}\left\{\int_{-\infty}^{\infty} R_{1}(\tau) e^{-j 2 \pi F \tau} \mathrm{d} \tau\right\} \mathrm{d} F}{\int_{-\infty}^{\infty}|H(F)|^{2}\left\{\int_{-\infty}^{\infty}\left(R_{2}(\tau)+R_{3}(\tau)\right) e^{-j 2 \pi F \tau} \mathrm{d} \tau\right\} \mathrm{d} F}
$$

\section{2 数值解析}

前節において, 背景雑音光と共存する振幅変調レー ザ光に対する本検波系の出力 $\mathrm{SN}$ 比の一般式が導出 された. 本節では, 変調信号の種類, 変調度, 背景雑 音光の帯域幅(被変調レーザ光の所要带域), 実効光電 子数および入力 $\mathrm{CN}$ 比に関して具体的な出力 $\mathrm{SN}$ 比 を求めて，それぞれが出力 $S N$ 比に与える影響を調 へ，本検波系の特性を明確にする.

まず変調信号については始めにも説明したように， ベースバンド変調信号とバンドパス変調信号の二つの 場合を考え，それぞれの電力スペクトル密度 $W_{s l}(F)$ $W_{s h}(F)$ をとする。

$$
\begin{aligned}
& W_{s i}(F)= \begin{cases}G_{s} & 0<|F| \leq B_{s} \\
0 & \text { その他の周波数 }\end{cases} \\
& W_{s h}(F)= \begin{cases}G_{s} & F_{h}-B_{s} \leq|F| \leq F_{h}+B_{s} \\
0 & \text { その他の周波数 }\end{cases}
\end{aligned}
$$




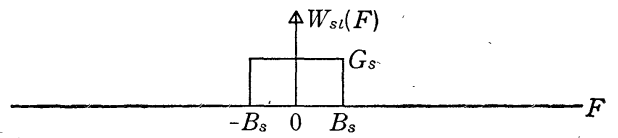

(a)

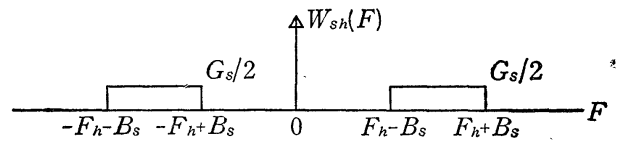

(b)

(a) Base band modulating $W_{s l}(F)$

(b) Bandpass modulating signal $W_{s h}(F) B_{s} \ll F_{h} \ll F_{0}$

Fig. 2 Power spectral density of the modulaing signal

ただし， $B_{s} \ll F_{h} \ll F_{0}$ であり，添字 $l, h$ はそれぞれ ベースバンド変調信号およびバンドパス変調信号を示 している. (33)，(34)式の関係が Fig. 2 に示されて いる.
】また, これらの変調信号を取出し，不必要な雑音 成分を取り除くために，光検波器の後につぎの周波数 特性をあつ理想出力フィルタを用いる

$$
\begin{aligned}
& \left|H_{l}(F)\right|= \begin{cases}1 & 0<|F|<B_{s} \\
0 & \text { その他の周波数 }\end{cases} \\
& \left|H_{h}(F)\right|= \begin{cases}1 & F_{h}-B_{s}<|F| F_{h}+B_{s} \\
0 & \text { その他の周波数 }\end{cases}
\end{aligned}
$$

さらに背景雑音光の電力スペクトル密度. $W_{A n l}(F)$, $W_{A n h}(F)$ については，ここでは理想的な光入力フィ ルタを用いるものとしてその帯域を被変調レーザ光の それと等しいものと仮定する。したがって，

$$
\begin{aligned}
& W_{A n l}(F)= \begin{cases}G_{n} & F_{0}-B_{s} \leq F \leq F_{0}+B_{s} \\
0 & \text { その他の周波数 }\end{cases} \\
& W_{A n h}(F)= \begin{cases}G_{n} & F_{0}-F_{h}-B_{s} \leq F \leq F_{0}+F_{h}+B_{s} \\
0 & \text { その他の周波数 }\end{cases}
\end{aligned}
$$

変調信号, 背景雑音光および出力フィルタに対すると れらの仮定のもとに(32)式を計算すれば出力 SN 比 はつぎのように求まる

$$
\begin{aligned}
& \left(\frac{\mathrm{S}}{\mathrm{N}}\right)_{A l}=\frac{1}{\left[\frac{3}{8} m^{2}+\frac{3}{8 a^{2}}+\frac{1}{2 m^{2} a^{2}}+\frac{3}{16 m^{2} a^{4}}+\frac{1}{2 \gamma}\left(1+\frac{1}{m^{2}}+\frac{1}{m^{2} a^{2}}\right)\right]} \\
& \left(\frac{\mathrm{S}}{\mathrm{N}}\right)_{A h}=\frac{1}{\left[\frac{1}{2 a^{2}}+\frac{1}{m^{2} a^{2}}+\frac{1}{2 m^{2} a^{2}}\left(1+\frac{f_{h}}{2}\right)+\frac{1}{\gamma}\left(1+\frac{1}{m^{2}}+\frac{1+f_{n}}{m^{2} a^{2}}\right)\right]}
\end{aligned}
$$

ただし，

$$
\begin{aligned}
m & =\sqrt{P_{s}}: \text { 実効変調度 } \\
a^{2}= & \frac{A^{2}}{4 G_{n} B_{s}}: \text { ベースバンド変調信号の場合の入力 } \\
& \mathrm{SN} \text { 比 } \\
f_{h} & =F_{h} / B_{s}
\end{aligned}
$$

である。また $\alpha$ については

$$
\gamma=\frac{\alpha A^{2}}{2 B_{s}}=\frac{\eta A^{2}}{2 h F_{0} B_{s}}
$$

であって，変調信号の帯域幅の逆数 $B_{s}^{-1}$ で与えられ る時間内にレーザ光によって放出される実効光電子数 である.

Fig. 3，4 の実線は(39)，(40)式の関係を示してい る，以下に近似式によってその特徴を明らかにしてお $<$.

(1) $a^{2} \ll 1$ の場合

(i) $a^{2} \ll \gamma$ のとき:

(注 2) バンドパス変調信号の場合の入力 $\mathrm{CN}$ 比は

$$
\frac{A^{2}}{4 G_{n}\left(F_{h}+B_{s}\right)}=\frac{A^{2}}{4 G_{n} B_{s}\left(1+f_{h}\right)}=\frac{a^{2}}{1+f_{h}}
$$

であるので， $a^{2}$ と $f_{h}$ とから決められるが $a^{2}$ に比例 する.

$$
\begin{aligned}
\left.\searrow \quad\left(\frac{\mathrm{S}}{\mathrm{N}}\right)_{A l}\right|_{\substack{a^{2} \ll 1 \\
a^{2} \ll \gamma}}=\frac{16}{3} m^{2} a^{4} \\
\left.\quad\left(\frac{\mathrm{S}}{\mathrm{N}}\right)_{A h}\right|_{\substack{a^{2} \ll 1 \\
a^{2} \ll \gamma}}=2 m^{2} a^{4} /\left(1+\frac{f_{n}}{2}\right)
\end{aligned}
$$

このときの出力雑音成分はほとんど背景雑音光の 2 次 ひずみ成分であり，したがって出力 $\mathrm{SN}$ 比は $a^{2}$ の 2 乗に比例するとともにバンドパス変調信号の場合には 変調信号の中心周波数の影響を受ける。

(ii) $a^{2} \gg \gamma$ のとき :

$$
\begin{aligned}
& \left.\left(\frac{\mathrm{S}}{\mathrm{N}}\right)_{A l}\right|_{\substack{a^{2} \ll 1 \\
a^{2} \gg r}}=2 m^{2} a^{2} \gamma \\
& \left.\left(\frac{\mathrm{S}}{\mathrm{N}}\right)_{A h}\right|_{\substack{a^{2} \ll 1 \\
a^{2} \gg r}}=m^{2} a^{2} \gamma /\left(1+f_{h}\right)
\end{aligned}
$$

このときの出力雑音成分は背景雑音光によるショット 雑音の影響によるものであり，したがって $a^{2}$ 以外に $\gamma$ に比例し，またバンドパス変調信号の場合には変調 信号の中心周波数が影響する.
(2) $a^{2} \gg 1$ の場合
(iii) $a^{2} \ll \gamma$ のき : 


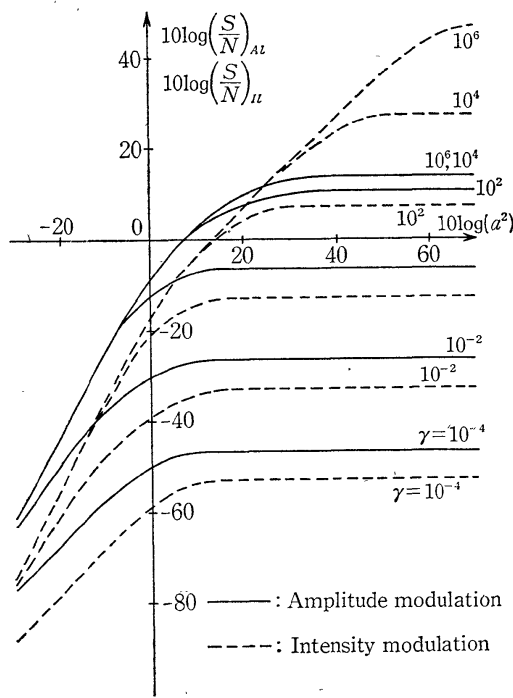

Fig. 3 Output signal-to-noise ratios (Base band modulating sugnal $m=1 / 3$ )

$$
\begin{aligned}
& \left.\left(\frac{\mathrm{S}}{\mathrm{N}}\right)_{A l}\right|_{\substack{a^{2} \ll 1 \\
a^{2} \gg \gamma}}=\frac{8}{3} m^{2} \\
& \left.\left(\frac{\mathrm{S}}{\mathrm{N}}\right)_{A h}\right|_{\substack{a^{2} \ll 1 \\
a^{2} \gg \gamma}}=\frac{a^{2}}{\left(\frac{1}{2}+\frac{1}{m^{2}}\right)}
\end{aligned}
$$

ベースバンド変調信号では必然的に生じる変調信号の 2 次ひずみ成分が出力 SN 比の限界を与えている. 一方，バンドパス変調信号では変調信号の 2 次ひずみ 成分は出力フィルタの帯域内には入ってこないので, $a_{\text {L }}^{2 !}$ に比例して出力 $\mathrm{SN}$ 比は大きくなる.

(iv) $a^{2} \gg r$ のとき

$$
\begin{aligned}
& \left.\left(\frac{\mathrm{S}}{\mathrm{N}}\right)_{A l}\right|_{\begin{array}{l}
a^{2} \gg 1 \\
a^{2} \gg r
\end{array}}=\frac{1}{\left[\frac{3}{8} m^{2}+\frac{1}{2 \gamma}\left(1+\frac{1}{m^{2}}\right)\right]} \\
& \left(\frac{\mathrm{S}}{\mathrm{N}}\right)_{\begin{array}{c}
A h \\
a^{2} \gg 1 \\
a^{2} \gg r
\end{array}}=\frac{r}{\left(1+\frac{1}{m^{2}}\right)}
\end{aligned}
$$

ベースバンド変調信号の場合には変調信号の 2 次ひず み成分以外に被変調レーザ光自身によるショット雑音 が加わる，一方，バンドパス変調信号の場合には変調 信号の 2 次ひずみ成分はないので, 被変調レーザ光自 身によるショット雑音だけとなり $\gamma$ に比例すること になる，また変調度に関しては, 当然のことながら, 変調度の大きいほうが出力 SN 比も大きい.

このように入力 $\mathrm{CN}$ 比の表示は変調信号の種類に よっても異なるし，また振幅変調と強度変調とによっ ても異なってくるが, すべて $a^{2}$ に比例していること には変わりなく，また背景雑音光の電力スペクトル密

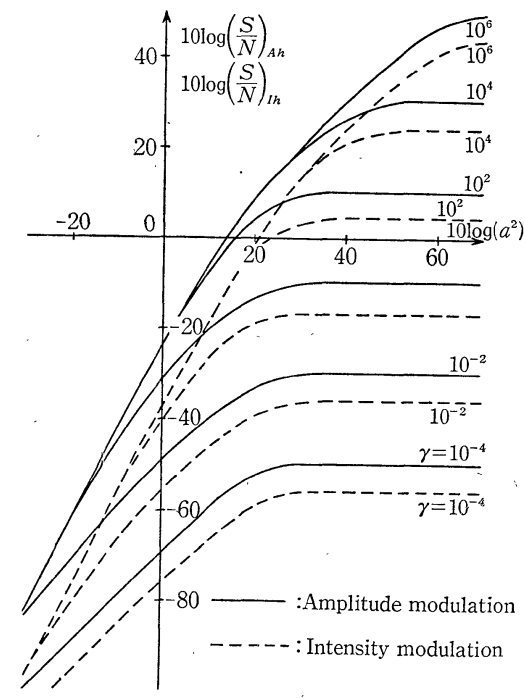

Fig. 4 Output signal-to-noise ratios (Bandpass modulating signal $m=1 / 3 \quad f_{h}=100$ )

度 $G_{n}$ が等しいという条件の屯とで変調方式や変調 信号を評価するほうが現実的であるので，以後入力 $\mathrm{CN}$ 比の大小を示すパラメータとしてての $a^{2}$ をを用い ることにする。

\section{3. 強度変調レーザ光に対する出カ $\mathrm{SN}$ 比}

レーザ光の変調方式のうちで重要な振幅変調につい ては前節までに解析されたので，本節ではあう一つの 重要な変調方式である強度変調の場合について理論的 考察を行ない，振幅変調の場合との比較を通じてその 特性を明らかにする.

\section{1 一般的解析}

強度変調レーザ光の入力複素電界 $V_{I}(t)$ はつぎのよ うに表現できる。

$$
V_{I}(t)=\sqrt{1+V_{s}(t)} V_{x}(t)+V_{n}(t)
$$

ここであ変調信号の平均電力 $P_{s}$ は $9^{-1}$ 以下とし, 過変調の影響を無視する. 瞬時強度 $I_{I}(t)$, 平均強度 $\left\langle I_{I}(t)\right\rangle$ は (2)，(3) 式に対応してつぎのようになる。

$$
\begin{aligned}
I_{I}(t)= & \left(1+V_{s}(t)\right) V_{x} *(t) V_{x}(t)+V_{n}^{*}(t) V_{n}(t) \\
& +\sqrt{1+V_{s}(t)}\left(V_{x} *(t) V_{n}(t)+V_{x}(t) V_{n} *(t)\right.
\end{aligned}
$$

$$
\left\langle I_{I}(t)\right\rangle=\left\langle I_{x}(t)\right\rangle+\left\langle I_{n}(t)\right\rangle
$$

また，レーザ光および背景雑音光に対する定義 $(13)$ 〜 $(25)$ 式を用いると出力電流の自己相関関数 $R_{I}(\tau)$ は

$$
\begin{aligned}
& R_{I}(t) \\
& =\frac{1}{4} \alpha^{2} e^{2}\left[\langle ( 1 + V _ { s } ( t ) ) ( 1 + V _ { s } ( t + \tau ) ) \rangle \left\langleI_{x}(t) I_{x}(t\right.\right. \\
& \quad+\tau)\rangle+2\left\langle I_{x}(t)\right\rangle\left\langle I_{n}(t)\right\rangle+\left\langle I_{n}(t) I_{n}(t+\tau)\right\rangle
\end{aligned}
$$


$+\left\langle\sqrt{1+V_{s}(t)} \sqrt{1+V_{s}(t+\tau)}\right\rangle\left(R_{x} *(\tau) R^{u}(\tau)\right.$

$\left.+R_{x}(\tau) R_{n}^{*}(\tau)\right)+\frac{1}{2} \alpha e^{2}\left[\left\langle I_{x}(t)\right\rangle+\left\langle I_{n}(t)\right\rangle\right] \delta(\tau)$

となる.さらにV $\overline{1+V_{s}(t)}$ なる変調成分についてはテ ーラー展開表示すると

$$
\sqrt{1+V_{s}(t)}=1+\sum_{i=1}^{\infty} A_{i} V_{s}{ }^{i}(t)
$$

ただし

$$
\begin{aligned}
& A_{1}=\frac{1}{2}, \quad A_{i}=\left(\frac{1}{2}\right)(-1)^{i-1} \frac{(2 i-3) ! !}{i !}, \\
& (2 i-3) ! !=(2 i-3)(2 i-5) \cdots 3 \cdot 1
\end{aligned}
$$

と表わせる。（57)，(58)式を(56)式に代入して書き改 めると $R_{I}(\tau)$ は最終的につぎのようになる。

$$
\begin{aligned}
R_{I .}(\tau)= & \alpha^{2} e^{2}\left[\frac{A^{2}}{2}+P_{n}\right]^{2}+\alpha^{2} e^{2}\left[\frac{4}{A^{4} R_{s}(\tau)}+r_{n}{ }^{2}(\tau)\right. \\
& +A^{2}\left\{1+\left\langle\Sigma A_{i} V_{i}(t)\right\rangle\right. \\
& \left.+\left\langle\left(\sum A_{i} V_{s}{ }^{i}(t)\right)\left(\sum A_{j} V_{s}{ }^{j}(t+\tau)\right)\right\} r_{n}(\tau)\right] \\
& +\alpha e^{2}\left[\frac{A^{2}}{2}+P_{n}\right] \delta(\tau)
\end{aligned}
$$

ここで,

$$
\begin{aligned}
& \left\langle\sum A_{i} V_{s}{ }^{i}(t)\right\rangle=\sum_{i=1}^{\infty} A_{2 i}(2 i-1) ! ! P_{s}{ }^{i} \\
& \left\langle\left(\sum A_{i} V_{s}{ }^{i}(t)\left(\sum a_{j} V_{s}{ }^{j}(t+\tau)\right)\right\rangle\right. \\
& =\sum_{i=1}^{\infty} \sum_{j=1}^{\infty}\left[A _ { 2 i } A _ { 2 j } \sum _ { k = 0 } ^ { j } { } _ { 2 j } C _ { 2 k } \left\{\sum_{l=0}^{k}{ }_{k} C_{l}(-1)^{l}\right.\right. \\
& \left.\quad \times \psi_{s}(\tau)^{2(i+l-k)}\right\}(2 i+2 j-2 k-1) ! ! P_{s}^{i+j} \\
& \quad+A_{2 i-1} A_{2 j-1} \sum_{k=0}^{j-1} 2{ }^{2 j-1} C_{2 k}\left\{\sum_{l=0}^{k}{ }_{k} C_{l}(-1)^{l}\right. \\
& \left.\left.\quad \times \psi_{s}(\tau)^{2(j+l-k)-1}\right\}(2 i+2 j-2 k-3) ! ! P_{s}{ }^{i+j-1}\right]
\end{aligned}
$$

ただし, $\psi_{s}(\tau)=R_{s}(\tau) / P^{s}$

(59)式の右辺の内容は第 1 項は直流分, 第 2 項は出力 信号成分および波動干渉雑音，第 3 項はショット雑音 である. このように $R_{I}(\tau)$ は一般には無限級数之な り，複雑であるが(60), (61) 式は $P_{s} \leq 9^{-1}$ であるとと を考え合わせれば収束が早いので， $P_{s}$ に関して高次 のむのを無視して最高 3 次の項で近似して $R_{I}(\tau)$ を 簡単化し出力成分を明らかにする.まず(60), (61) 式 を近似すれば

$$
\begin{aligned}
& \text { (61) 式 } \fallingdotseq-\frac{P_{s}}{8}-\frac{15 P_{s}^{2}}{128} \\
& \text { (62) 式 } \fallingdotseq\left(\frac{1}{4}+\frac{3 P_{s}}{16}\right) R_{s}(\tau)+\frac{5 R_{s}^{2}(\tau)}{64}+\frac{3 R_{s}{ }^{3}(\tau)}{16 P_{s}}
\end{aligned}
$$

となるので出力自己相関関数 $R_{I}(\tau)$ は

$$
\begin{aligned}
R_{I}(\tau)= & \alpha^{2} e^{2}\left[\frac{A^{2}}{2}+P_{n}\right]^{2}+\alpha^{2} e^{2}\left[\frac{A^{4} R_{s}(\tau)}{4}\right. \\
& ++A^{2}\left\{1-\frac{P_{s}}{4}-\frac{15 P_{s}^{2}}{64}+\left(\frac{1}{4}+\frac{3}{16}\right) P_{s} R_{s}(\tau)\right. \\
& \left.\left.+\frac{5 R_{s}^{2}(\tau)}{64}+\frac{3 R_{s}^{3}(\tau)}{16 P_{s}}\right\} r_{n}(\tau) r_{n}^{2}(\tau)\right] \\
& +\alpha e^{2}\left[\frac{A^{2}}{2}+P_{n}\right] \delta(\tau)
\end{aligned}
$$

このようにして, 強度変調レーザ光に対する光検波器 出力電流の自己相関関数が得られたので, 出力フィル タを通った成分のうち信号成分と雑音成分の比をとれ ば出力 $\mathrm{SN}$ 比が求まる.

\section{2 数值解析}

変調信号および出力フィルタに対する定義(33)〜 (36)式を用いて, 振幅変調の場合と同様ベースバンド 変調信号, バンドパス変調信号に対する出力 $\mathrm{SN}$ 比 を以下に求める．まず背景雑音光についてはその帯域 幅を被変調レーザ光の所要帯域と同じとするが, 被変 調レーザ光は(53)式に示されているように一般には $F_{0}$ を中心として $V_{s}(t)$ の無限次の高調波を含むので, 被変調レーザ光をひずみなく通すには光入力フィルタ としては無限大の带域をあつあのが必要となるが，実 際には(65)式の導出の際にも示したように $P_{s}$ に関す るたかだか 3 次の電力までを通す程度で十分と考えら れるので, 光入力フィルタの帯域幅としては $F_{0}$ を中 心に $V_{s}(t)$ の3次までを通すむのを仮定する．した がって, 光入力フィルタを通った背景雑音光の電力ス ペクトル密度 $W_{I n l}(F), W_{I n h}(F)$ をつぎのように定 める.

$$
\begin{aligned}
& W_{\text {Inl }}(F)= \begin{cases}G_{n} & F_{0}-3 B_{s} \leq F \leq F_{0}+3 B_{s} \\
0 & \text { その他の周波数 }\end{cases} \\
& W_{\text {Inh }}(F)=\left\{\begin{array}{cc}
G_{n} & F_{0}-3 F_{h}-3 B_{s} \leq F \leq F_{0} \\
0 & +3 F_{h}+3 B_{s} \\
0 & \text { その他の周波数 }
\end{array}\right.
\end{aligned}
$$

この場合の出力 $\mathrm{SN}$ 比はつぎのようになる.

$$
\begin{aligned}
\left(\frac{\mathrm{S}}{\mathrm{N}}\right)_{I l}= & 1 /\left[\left\{\frac{2}{m^{2}}-\frac{1}{4}+\frac{2865 m^{2}}{74752}\right\} / a^{2}+\frac{11}{4 m^{2} a^{4}}\right. \\
& \left.+\frac{1}{\gamma}\left(\frac{1}{m^{2}}+\frac{3}{m^{2} a^{2}}\right)\right] \\
\left(\frac{\mathrm{S}}{\mathrm{N}}\right)_{I h}^{=}= & 1 /\left[\left\{\frac{4}{m^{2}}-\frac{1}{2}+\frac{33 m^{2}}{64}\right\} / a^{2}+\frac{6+5 f_{n}}{m^{2} a^{4}}\right. \\
& \left.+\frac{4}{\gamma}\left(\frac{1}{m^{2}}+\frac{3+3 f_{n}}{m^{2} a^{2}}\right)\right]
\end{aligned}
$$

Fig. 3, 4 の点線は(68), (69)式の関係を示している. 以下に出力 $\mathrm{SN}$ 比に対する近似式を与え，振幅変 
調との比較を通じてその特性を明らかにする.

(1) $a^{2} \ll 1$ の場合

(i) $a^{2} \ll \gamma$ のとき:

$$
\begin{aligned}
& \left.\left(\frac{\mathrm{S}}{\mathrm{N}}\right)_{I l}\right|_{\substack{a^{2} \ll 1 \\
a^{2} \ll \gamma}}=\frac{4}{11} m^{2} a^{4} \\
& \left.\left(\frac{\mathrm{S}}{\mathrm{N}}\right)_{I h}\right|_{\substack{a^{2} \ll 1 \\
a^{2} \ll \gamma}}=\frac{m^{2} a^{4}}{\left(6+5 f_{n}\right)}
\end{aligned}
$$

この場合の出力雑音は背景雑音光の 2 次ひずみ成分で あるが(45)，(46)式と比べてみると，強度変調のほう が明らかに出力 SN 比の悪いととがわかる. その理 由としては，まず変調信号 $V_{s}(t)$ に関しては

振幅変調: $\left(1+V_{s}(t)\right)^{2}=1+2 V_{s}(t)+V_{s}{ }^{2}(t)(72)$

強度変調 $:\left(\sqrt{1+V_{s}(t)}\right)^{2}=1+V_{s}(t)$

であるから, 出力信号成分 $\left(V_{s}(t)\right.$ の項) は振幅変調 では強度変調の 4 倍の電力をもっている．加えて強度 変調の所要帯域は振幅変調より広い為にそれだけ背景 雑音光電力が大きいととによるあのである.

(ii) " $a^{2} \gg r$ のさ:

$$
\begin{aligned}
& \left.\left(\frac{\mathrm{S}}{\mathrm{N}}\right)_{I l}\right|_{\substack{a^{2} \ll 1 \\
a^{2} \gg r}}=\frac{1}{6} m^{2} \gamma a^{2} \\
& \left.\left(\frac{\mathrm{S}}{\mathrm{N}}\right)_{I h}\right|_{\substack{a^{2} \ll 1 \\
a^{2} \gg r}}=\frac{m^{2} r a^{2}}{\left(12+12 f_{n}\right)}
\end{aligned}
$$

この場合の出力雑音は背景雑音光に基づくショット雑 音であるので，（i ）の場合之同様出力 $\mathrm{SN}$ 比は振幅 変調のほうが優れている。

(2) $a^{2} \gg 1$ の場合

(iii) $a^{2} \ll \gamma$ のとき :

$$
\left.\left(\frac{\mathrm{S}}{\mathrm{N}}\right)_{I l}\right|_{\substack{a^{2} \gg 1 \\ a^{2} \ll \gamma}}=a^{2} / \frac{1}{2} m^{2} \quad\left(\frac{\mathrm{S}}{\mathrm{N}}\right)_{\substack{I h \\ a^{2} a^{2} \ll \gamma}}=\frac{a^{2}}{36}
$$

出力 SN 比は $a^{2}$ に比例して増加する. ベースバン ド変調信号の場合に㧧いては，振幅変調のときに生じ た変調信号の 2 次ひずみ成分は強度変調のときには現 われないので出力 $\mathrm{SN}$ 比は強度変調のほうがよい. 一方バンドパス変調信号の場合には, 強度変調での出 力信号電力が小さいととによる分だけ出力 $\mathrm{SN}$ 比も 悪い.

(iv) $a^{2} \gg \gamma$ のとき:

$$
\left.\left(\frac{\mathrm{S}}{\mathrm{N}}\right)_{I l}\right|_{\substack{a^{2} \gg 1 \\ a^{2} \gg \gamma}}=\frac{m^{2}}{2} \gamma \quad\left(\frac{\mathrm{S}}{\mathrm{N}}\right)_{\substack{I h \\ a^{2} \gg 1 \\ a^{2} \gg \gamma}}=\frac{m^{2}}{4} \gamma
$$

この場合の出力雑音は被変調レーザ光自身によるショ ット雑音である． $m^{2} \leq 9^{-1}$ を考慮に入れて (78)，(79) 式と(51)，(52)式を比べてみると，ともに(51)，(52)式
のほうが約 4 倍良好であることがわかる．すなわち出 力信号成分の大きさだけ振幅変調が強度変調より優れ ている.

以上の近似による振幅変調との比較の結果, 入力 $\mathrm{CN}$ 比执よび実効光電子数が十分大きく， かつベース バンド変調信号を用いる場合にのみ強度変調が有効と なるととが明らかとなった。

\section{4. むすび}

以上，振幅変調あるいは強度変調を受けたレーザ光 が背景雑音光としてともに光検波器入力となるときの 出力 SN 比について理論的解析を行ない, 変調方式, 変調度, 変調信号の種類, 実効光電子数, 波動干渉雑 音, ショット雑音および入力 $\mathrm{CN}$ 比などが出力 $\mathrm{SN}$ 比に及ぼす影響について詳細に論じた。 これらの要素 をすべて考慮に入れて出力 $\mathrm{SN}$ 比の比較を行なうこ とは一般には非常に複雑であるが，第 2 節と第 3 節の 終わりに，それぞれ近似式による比較を試み本質的な 特性を明確にしている，てのように本論文では，従来 あまり明確にされていなかったアナログ AM レーザ 方式の出力特性に関して, 種々の要因を考慮すること によってより厳密な出力 $\mathrm{SN}$ 比を与え，レーザ計測 分野におけるシステム評価基準に対する有用な一資料 を提供するものである。

\section{参 考 文 献}

1) B. Reiffen, H. Sherman: "An optimum demodulator for Poisson process: photon source detectors", Proc. IEEE, 51, 1316 (Oct. 1963)

2) R. M. Gagliardi, S. Karp: "M-ary Poisson detection and optical communication", IEEE Trans. Communication Technology, COM-17-2, 208 (April 1969)

3) S. Karp, E. L. O'Neill, R. M. Gagliardi: “Communication Theory for the tree-space optical channel" Proc. IEEE, 1611 (Oct. 1970)

4) S. Karp, J. R. Clark: "Photon Counting; A problem in classical noise theory", IEEE Trans. Information Theory, IT-16-6, 672 (Nov. 1970)

5) S. Karp, R.M. Gagliardi: "The design of a pulse position modulated optical communication systems" IEEE Trans. COM-17-6, 670 (Dec. 1969)

6）小林：レーザ応用技術，日刊工業新聞社 p. 145 (1969)

7) 文献 ${ }^{11}$, p. 123

8）市村, 稲場：極微弱光の情報検出法の研究，応用物理, 39-9, 913 (1969)

9) E. B. Felstead.: "A simple real-time in coherent. optical correlator", IEEE Trans. on Aerospace and Electronic System, AES-3, 907 (Nov. 1967)

10) T. Namekawa, S. Kawachida: "Application of in tensity-modulated light by an ultrasonic light modulator to the optical processor", Electronic letters, 18-12 (June 1972)

11) W.K. Pratt: "Laser Communication systems", John Wiley \& Sons, 174 (1969)

12) L. Mandel: "Heterodyne Detection of a Weak Light Beam", JOSA, 56 (Sept. 1966)

13) H. Hodara: "Statistics of thermal and laser radiation", Proc.. IEEE, 53, 696 (July 1965) 